\title{
A Review of the Latest Trends in the Use of Green Ammonia as an Energy Carrier in Maritime Industry
}

\author{
George Mallouppas *, Constantina Ioannou and Elias Ar. Yfantis
}

check for updates

Citation: Mallouppas, G.; Ioannou,

C.; Yfantis, E.A. A Review of the Latest Trends in the Use of Green Ammonia as an Energy Carrier in Maritime Industry. Energies 2022, 15, 1453. https://doi.org/10.3390/ en15041453

Academic Editors: Giovanni Cinti, Andrzej Teodorczyk and Gabriele Di Blasio

Received: 30 December 2021 Accepted: 15 February 2022 Published: 16 February 2022

Publisher's Note: MDPI stays neutral with regard to jurisdictional claims in published maps and institutional affiliations.

Copyright: () 2022 by the authors. Licensee MDPI, Basel, Switzerland. This article is an open access article distributed under the terms and conditions of the Creative Commons Attribution (CC BY) license (https:// creativecommons.org/licenses/by/ $4.0 /)$.

\author{
Marine and Offshore Science, Technology, and Engineering Centre, Cyprus Marine and Maritime Institute, \\ Larnaca 6023, Cyprus; constantina.ioannou@cmmi.blue (C.I.); elias.yfantis@cmmi.blue (E.A.Y.) \\ * Correspondence: george.mallouppas@cmmi.blue
}

\begin{abstract}
This review paper examines the key barriers to using green ammonia as an alternative fuel in maritime industry. A literature survey is performed based on research articles and grey literature, with the aim of discussing the technoeconomic problems with and benefits of ammonia and the relevant technologies. The limitations of ammonia as a maritime fuel and its supply chain, the expected percentage demand by 2030 and 2050, its economic performance compared to other shipping fuels such as hydrogen, and the current regulations that may impact ammonia as a maritime fuel are discussed. There are several key barriers to ammonia's wide adoption: (1) High production costs, due to the high capital costs associated with ammonia's supply chain; (2) availability, specifically the limited geographical locations available for ammonia bunkering; (3) the challenge of ramping up current ammonia production; and (4) the development of ammonia-specific regulations addressing issues such as toxicity, safety, and storage. The general challenges involved with blue ammonia are the large energy penalty and associated operational costs, and a lack of technical expertise on its use. Regardless of the origin, for ammonia to be truly zero-carbon its whole lifecycle must be considered-a key challenge that will aid in the debate about whether ammonia holds promise as a zero-carbon maritime fuel.
\end{abstract}

Keywords: green ammonia; ammonia as an energy carrier; decarbonisation; International Maritime Organisation

\section{Introduction}

Shipping represents about 3\% of total global greenhouse emissions [1]; therefore, regulations regarding $\mathrm{CO}_{2}$ emissions and harmful emissions, such as $\mathrm{NO}_{\mathrm{x}}, \mathrm{SO}_{\mathrm{x}}$, are "set to promote major technological changes in the industry" $[2,3]$. To put matters into perspective, if the shipping industry were a country, it would rank as the 6th-highest emitter, ahead of Germany and the UK [4]. The International Maritime Organisation (IMO) has set an ambitious decarbonisation target of reducing the $\mathrm{CO}_{2}$ emissions from shipping by at least $50 \%$ by 2050 compared with the 2008 baseline [5]. Decarbonisation options for the maritime sector exist, such as green ammonia and green hydrogen technologies, but are limited due to the following key implementation barriers, namely: (1) cost, (2) fuel storage, (3) additional storage space demand, (4) technical maturity, (5) high fuel price, (6) limited availability, (7) lack of global bunkering infrastructure, (8) safety, and (9) lack of regulations [4]. Hence, using the currently available technologies, the most practical and pragmatic plan to achieve zero emissions includes the use of LNG and LPG as a bridge solution. On the other hand, transition fuels, such as LNG, still emit $\mathrm{CO}_{2}$ when produced nonrenewably and, thus, we cannot ignore the potential of other alternative fuels, such as ammonia, despite their current drawbacks. Furthermore, fuels such as LNG can have a negative impact on the environment due to "methane slip." Methane is a much more potent greenhouse gas than $\mathrm{CO}_{2}$ [6].

Current methods of producing ammonia typically use fossil fuels to create a hydrogen feedstock and then, via the energy-intensive Haber-Bosch process, combine hydrogen and 
nitrogen with the help of high temperatures, high pressures, and a catalyst [7-9]. Aziz et al. provided an overview of the production, storage, and utilization of ammonia [10]. In their review, they mention that ammonia can be produced either by renewable energy sources or fossil fuels and show that ammonia can be used directly, or effectively used a hydrogen energy carrier, due to its excellent physical properties. On the other side, air separation units are typically needed to isolate and provide the nitrogen feedstock. In 2020, global ammonia production accounted for $2 \%$ of total energy consumption and $1.3 \%$ of $\mathrm{CO}_{2}$ emissions [11-14]. In recent years, the use of ammonia as a marine fuel has gained momentum $[7,15,16]$. Solar, wind, or hydropower is needed in order to produce green ammonia renewably. The quantities needed to supply the shipping industry with ammonia as a fuel will need to increase and, therefore, the corresponding $\mathrm{CO}_{2}$ emissions could increase if ammonia is not produced renewably [7,17]. As a result, the production of ammonia by renewable energy is imperative. However, green ammonia production is not yet cost-effective compared to conventional fossil fuel-based ammonia. Presently, 90\% of current ammonia production depends on fossil fuels such as natural gas [18].

Blue ammonia, which can be produced using carbon capture and storage (CCS) systems, can mitigate the increase in $\mathrm{CO}_{2}$ emissions. However, $\mathrm{CCS}$ technologies are at an early stage of research and development, so not ready for commercialization, and are not cost-effective [6]. Currently, there is considerable activity in the research and development of ammonia-powered vessels. In fact, Mapping of Zero Emission Pilots and Demonstration Projects, a report by the Getting to Zero Coalition, identified 14 shipping technology concept studies, pilots, and demonstrations that focused on ammonia-powered shipping undertaken in Japan, China, South Korea, Greece, and Northern Europe, with an additional nine projects on production and fuelling infrastructure for ships [19]. These projects cover the whole value chain, "focusing on different elements for the transition of shipping to zero emission fuels" [19]. In this respect, studies such as the one performed by Dincer et al. [20] evaluating the lifecycle performance of ammonia production are necessary to determine the implications of the production process for the environment, in terms of global warming potential, and also to consider other factors impacting the environment. For example, in their study, considering the current capabilities and efficiencies, the green ammonia produced from PVs has a significant environmental impact in terms of toxicity, acidification, and eutrophication. This is because of the low efficiencies of current PV systems; hence, the large number of cells and corresponding area needed to produce the necessary power. Nonetheless, a more credible alternative for ammonia production may be wind-based electrolysis [20]. Furthermore, the authors mention that ammonia produced using biomass has the most "benign" impact on the environment [20].

Zero-emission shipping must be built on three pillars: (1) retrofitting and/or designing new vessels with the ability to use zero-emission, alternative fuels, so the design must incorporate safety, reliability, and proven performance in an operational context; (2) the use of zero-emission fuels that can be produced in sufficient (yet sustainable) quantities to satisfy the current and growing demand, and (3) financing and investment (in "existing and new infrastructure necessary to decarbonize shipping across the value chain") [21]. Any measure or new technology involving ammonia as a fuel will need public acceptance. In a recent online survey conducted in the UK and Mexico, Guati-Rojo et al. [22] suggest that most participants support the development of green ammonia technologies; however, the corresponding perception is highly dependent on the associated risks and benefits. Consequently, public acceptance of an energy technology is complex and difficult to study [22].

The scope of this review paper is based on research articles and grey literature and discusses the potential use of ammonia as a maritime fuel. Specifically, the review paper aims to answer the specific research questions, which are: (1) Do we need to invest in blue or green ammonia? (2) What percentage of maritime fuel demand will be met by ammonia in 2030/2050? (2) What is the expected adoption of ammonia for different shipping/vessel segments and different geographical regions? (3) What are the advantages 
and disadvantages of ammonia versus other green ship fuels? (4) What is the economic performance of ammonia versus other ship fuels-and how will this develop by 2030/2050? and (5) What are the regulations impacting ammonia as a fuel? Finally, the review paper will conclude with a summary and future recommendations.

\section{Advantages and Disadvantages of Ammonia Versus Other Green Ship Fuels}

Ammonia allows more hydrogen storage in liquid form without the need for cryogenic storage $\left(-33.4{ }^{\circ} \mathrm{C}\right.$ for ammonia compared to $-252.9{ }^{\circ} \mathrm{C}$ for hydrogen), thus making $\mathrm{NH}_{3}$ a suitable hydrogen carrier [18]. Hydrogen is far more expensive to store than ammonia, despite the fact that both fuels have similar energy densities [18]. There are numerous barriers to ammonia becoming a competitive fuel in shipping's transition to decarbonisation, namely (1) an "appropriate ammonia-fuelled power generator, (2) appropriate system safety assessment tool, and (3) mitigating measures to address the hazards of ammonia" [23]. Hydrogen handling and safety are important issues to address. Ammonia storage is generally simpler than that of hydrogen [23]. Another limitation of hydrogen, as shown in Table 1 , is that it has a low energy density $\left(4.7 \mathrm{GJ} / \mathrm{m}^{3}\right)$ in gaseous form compared to liquefied hydrogen $\left(8.5 \mathrm{GJ} / \mathrm{m}^{3}\right)$; however, liquefying hydrogen is an energy-intensive process [24]. In the longer term, "zero-carbon energy carriers" such as hydrogen and ammonia offer the most promising pathways to decarbonize shipping; however, biofuels, in the short to medium term, are most suitable for "retrofits and existing infrastructure" [25]. In addition, the NoGAPS project concluded that it is envisioned that ammonia synthesized from green hydrogen "represents a credible long-term, zero-emission fuel" [21]. The NoGAPS project also concluded that "the potential of ammonia-powered shipping to contribute to the decarbonization of the maritime sector is significant, and ammonia carriers present a logical starting point for demonstrating this potential" [21]. However, and most importantly, government support and public finance can accelerate investment now, which can improve the long-term prospects for ammonia deployment as a shipping fuel [21].

Table 1. Properties of alternative marine fuels, reproduced from [23].

\begin{tabular}{|c|c|c|c|c|c|}
\hline Fuel & $\begin{array}{c}\text { Energy Density } \\
\text { LHV (MJ/kg) }\end{array}$ & $\begin{array}{c}\text { Volumetric } \\
\text { Energy Density } \\
\left(\mathrm{GJ} / \mathrm{m}^{3}\right)\end{array}$ & $\begin{array}{c}\text { Renewable Synthetic } \\
\text { Production Cost } \\
(\mathrm{MJ} / \mathrm{MJ})\end{array}$ & $\begin{array}{l}\text { Storage Pressure } \\
\text { (Bar) }\end{array}$ & $\begin{array}{l}\text { Liquefied Storage } \\
\text { Temperature }\left({ }^{\circ} \mathrm{C}\right)\end{array}$ \\
\hline $\begin{array}{l}\text { Compressed } \\
\text { hydrogen }\end{array}$ & 120 & 4.7 & 1.7 & 700 & 20 \\
\hline Liquid hydrogen & 120 & 8.5 & 1.8 & 1 & -253 \\
\hline Ethanol & 26.7 & 21.1 & 3.6 & 1 & 20 \\
\hline Methanol & 19.9 & 15.8 & 2.6 & 1 & 20 \\
\hline Liquid methane & 50 & 23.4 & 2.3 & 1 & -162 \\
\hline Liquid ammonia & 18.6 & 12.7 & 1.8 & 1 or 10 & -34 or 20 \\
\hline
\end{tabular}

In addition to hydrogen, there are other alternative fuels that compete with ammonia. These are alcohols (ethanol and methanol), natural gas, biodiesel, and, to a lesser extent, biogas. There has been interest in methanol as a marine fuel [7], with notable examples being the retrofitting of a Stena Line ferry [26] and the recent order from A. P. Moller-Maersk of a container ship operating with e-methanol [27], with MAN Energy Solutions developing dual-fuel engines [28]. Natural gas (which is $90 \%$ methane) is the most competitive alternative to traditional marine fuels. As shown in Table 1, methane (whose properties are considered identical to natural gas) has the highest volumetric energy density $\left(23.4 \mathrm{GJ} / \mathrm{m}^{3}\right)$. Methane has the added benefit of lower $\mathrm{CO}_{2}$ and NOx emissions, almost nonexistent PM emissions, and zero Sox emissions. Table 1 shows that ethanol and methanol are competitive alternative fuels due to their relatively high volumetric energy density $\left(21.1 \mathrm{GJ} / \mathrm{m}^{3}\right.$ and $15.8 \mathrm{GJ} / \mathrm{m}^{3}$, respectively). Note that ethanol methanol and liquid ammonia, compared to liquid methane, have almost half the energy density, which means that, to achieve the same power output, twice the amount of fuel is required [23], which implies higher storage 
costs and less space on vessels to transport goods. The situation is even worse for liquefied or compressed hydrogen, despite having the largest energy density on a LHV basis. It is worth mentioning that ethanol and methanol can be produced from renewable energy sources, whereas natural gas is extracted from fossil fuels [23]. In the short term, transition fuels such as LNG and LPG are necessary due to the low availability of green fuels such as ammonia and hydrogen, which are expected to be dominant in the longer term.

\section{Ammonia in Various Technologies}

Ammonia can be used as a drop-in fuel in diesel in internal combustion engines and gas turbines and as a primary fuel in fuel cells, making it a very appealing and competitive alternative $[6,18,23]$. However, as Imhoff et al. suggest in their study, "naval vessels are less likely to adopt ammonia powertrains without significant redesigns" [29]. They further state that, if ammonia can be used as an alternative marine fuel, the powertrain design concept must prove that it is practically possible. Note that, in the study by Imhoff et al., the powertrain includes an engine, a waste heat recovery (WHR) heat exchanger (HX), an exhaust aftertreatment system, a fuel tank, a fuel heater, and an ammonia cracker [29].

\subsection{Internal Combustion Engines}

Combusting ammonia in internal combustion engines (ICEs) is not a new concept, but is an attractive option because of the absence of carbon and sulphur in ammonia's chemical formula. Thus, emissions of $\mathrm{CO}_{2}, \mathrm{CO}, \mathrm{UHC}, \mathrm{PM}$, and SOx are virtually eliminated. Ammonia and hydrogen have higher octane ratings than gasoline, are favourable at higher compression ratios [30], and thus are ideal for diesel engines [30]. Ammonia has a high autoignition temperature, so the dual-fuel approach [31] may be the way forward [6].

There are recent examples of interest in ammonia as a fuel for internal combustion engines. Recently, Wärtsilä, with Knutsen OAS Shipping AS, Repsol, and the Sustainable Energy Catapult Centre will test ammonia in a marine four-stroke internal combustion engine (the DEMO 2000 program) [32]. Preliminary tests in dual-fuel spark ignited engines have been performed by Wärtsilä, which "will be followed by field tests in collaboration with ship owners from 2022, and potentially also with energy customers in the future" [33]. MAN Energy solutions have also tested ammonia in their engines and "claim that their dualfuel engine developed for LPG may use liquid ammonia in a dual-fuel setup" [34,35]. In addition, "MAN Energy Solutions, Shanghai Merchant Ship Design and Research Institute (SDARI) and American Bureau of Shipping (ABS) have a development project for an ammonia-fueled feeder container vessel intended to use this technology" [34]. WinGD, in a press release, announced that methanol and ammonia engines will be available by 2024 and 2025, respectively [36].

Ammonia has several limitations that inhibit its commercial exploitation [33]. These are:

- Poor ignition

- Slow flame propagation speed compared to other fuels.

- High toxicity and corrosiveness, thus the requirement for sustainable safety and storage solutions.

- High NOx emissions, unless these are controlled either by after-treatment such as Selective Catalytic Reduction or by optimizing the combustion process.

- High costs in production by considering the supply chain and life-cycle considerations, especially if ammonia is produced renewably.

- $\quad$ Lack of regulations if ammonia is to be used as a marine fuel.

Due to the aforementioned constraints, unknowns, and issues, industry tests in the coming years will determine whether ammonia will become the next alternative fuel for internal combustion engines. Note that vessel engines currently operating on ammonia "still require small amounts of a pilot fuel to combust, therefore it is important that the pilot fuel should also be carbon zero" $[37,38]$. Innovative solutions such as mixing ammonia with hydrogen can improve reactivity in the dual-fuel mode; for example, mixing $30 \%$ hydrogen by volume can increase the laminar flame speed [12,39]. Irrespective of the technological 
difficulties, the first commercial two-stroke ammonia engine is expected to be available in 2024 [40].

\subsection{Fuel Cells}

The most efficient method for extracting energy from ammonia is via a fuel cell [7,41,42] with less noise, reduced air pollutants, and a lower space requirement compared to ICEs [17]. Fuel cells, compared to batteries, provide higher energy density with fewer repercussions for the environment (i.e., lower toxicity) [42]. The fact that fuel cells can be powered with green fuels such as ammonia and hydrogen has made this type of technology very promising [23]. In fact, interest in using ammonia as a fuel for fuel cells in maritime applications is growing [43]. An example is ShipFC, which is a funded project by the Fuel Cells and Hydrogen Joint Undertaking (FCH JU) under the EU's Horizon 2020 research and innovation program. The project is to install and test fuel cells using green ammonia in Viking Energy, an offshore vessel owned and operated by Eidesvik [44]. Compared to ICEs, cost-wise, fuel cells are more expensive, which is the main hurdle to their adoption in shipping $[4,17,45]$. "The most promising fuel cell types for the maritime sector are proton exchange membrane fuel cells (PEMFC) and solid oxide fuel cell (SOFC)" [17] because the former is already used in road transportation with relatively high maturity. The latter can use ammonia directly (PEMFC ammonia is used as a carrier for hydrogen) with resulting high power densities [46]. Afif et al. [46] rightfully mention that SOFC technology is not yet at the commercialization stage. A recent study by Kim et al. [47] examined the environmental and economic performance of ammonia as a possible fuel on a 2500 Twenty-foot Equivalent Unit container feeder ship for the following propulsion technologies: (1) main engine, (2) generators, (3) PEMFC, and (4) SOFC. The systems were compared with equivalent heavy fuel oil, and they determined that SOFC is the most environmentally friendly option although it has high lifecycle costs. However, case studies are required on all ship types to reach universal conclusions.

\section{Blue Versus Green Ammonia}

The production costs of green ammonia are higher than those of "traditional" ammonia and fossil fuels [21]. However, these costs are expected to decrease, as evidenced in a later section of this report.

The current challenges for CCS in general, as mentioned by Al-Hamed and Dinser [48], are: (1) the large energy penalty due to a reduction in the overall efficiencies of power plants, which translates into high operation and maintenance costs; (2) a lack of technical expertise due to the unavailability of plants with CCS, except for chemical absorbent plants; and (3) incorrect public perceptions regarding the maturity of renewable energy sources and the consequent underestimation of the ability of CCS technologies. These general challenges are equally applicable to the shipping industry. McKinlay et al. [7] rightfully mention that for "a fuel to be truly zero emission, then production and supply" should be emissions-free. This means that embodied energy (or embodied carbon) life cycle considerations should be considered.

\section{Estimated Percentage of Ammonia as Maritime Fuel in 2030 and 2050}

Ammonia is a widely traded commodity produced in large quantities (approximately 200 million metric tons per year) by the chemical industry with a pre-existing supply chain, and is mostly used for fertiliser $[7,23,49,50]$. In other words, about $70 \%$ of ammonia production is in the fertilizer industry, while the rest is part of various industrial applications, such as plastics, explosives, and synthetic fibres [11]. This implies that ammonia has existing supply chains and availability in the proximity of ports [23], albeit not all ports. Given that fertilisers are used to produce food and that the human population is rising, similarly to biomass, there is the moral argument of "food vs. fuel." Nonetheless, as IEA has rightly mentioned, in "the future, the world will need more ammonia but with fewer emissions" [11]. 
Ammonia is a more cost-effective solution than hydrogen due to both the lower price of the fuel and the existing infrastructure used in the fertilizer industry [23]. The existing infrastructure, in terms of transportation and handling, provides a competitive advantage over hydrogen $[51,52]$. Figure 1 shows the maritime energy demand and projected fuel mix up to 2050, as reported by the DNV GL in its Maritime Forecast to 2050 annual report in Energy Transition Outlook [4]. Figure 1 illustrates one likely pathway to meet the International Maritime Organisation's (IMO) 2050 targets. By 2050, it is evident that ammonia will play a significant role. It is clear from Figure 1 that, by 2030, ammonia and hydrogen will not play a significant role in the projected fuel mix. In fact, shipowners and industry analysts expect that ammonia will "play a pivotal role" in the decarbonization of shipping [53] beyond 2030 .

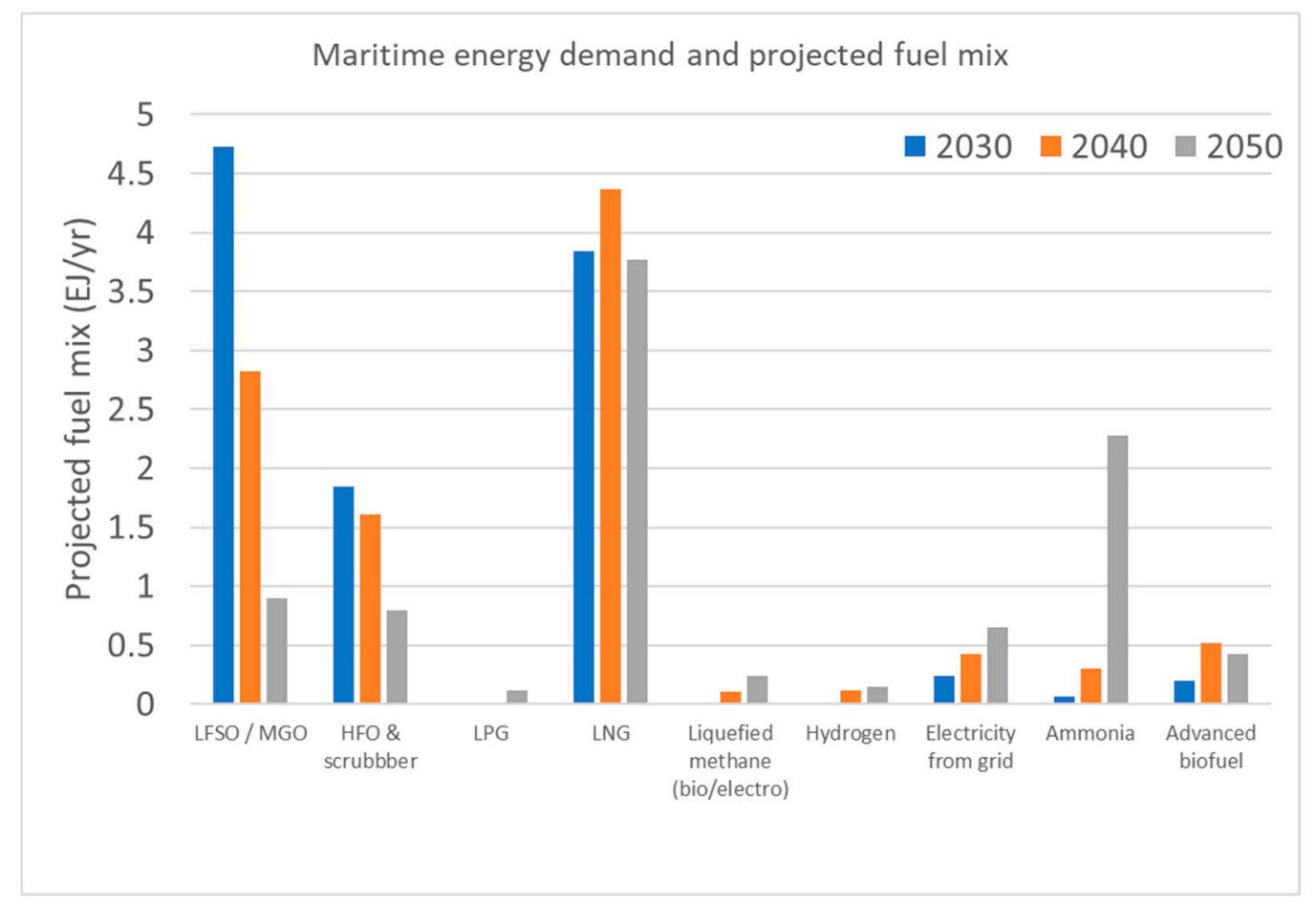

Figure 1. Maritime energy demand and projected fuel mix up to 2050, with data from [4].

Furthermore, Figure 1 illustrates the projected share of marine fuels by 2030 and 2050, clearly showing ammonia in this pivotal role, without separating the two fuels. According to DNV GL, "widespread commercial adoption of ammonia fuel would begin in 2037; ammonia would be the dominant fuel choice for new ships by 2042; and ammonia would represent $25 \%$ of the maritime fuel mix by 2050" [4,54]. A recent survey of shipping sector stakeholders by Lloyd's List identified ammonia as one of the top three fuels with potential for 2050 [55,56]. In addition, the survey showed the industry's expected "ammonia usage to grow to $7 \%$ of fuel by 2030 and $20 \%$ by 2050 " [55,56]. Therefore, the various reports show some variability in the expected ammonia uptake by the shipping industry, which can be expected to be $20-25 \%$ by 2050 . In a white paper published by Alfa Laval, Hafnia, Haldor Topsøe, Vestas, and Siemens Gamesa, regarding ammonia as fuel in the shipping industry, it is mentioned that by 2050 the additional ammonia production would nearly double to meet the $30 \%$ fuel demand $[55,57]$, thus creating issues with the supply chain and relative availability of ammonia as a maritime fuel.

\section{Adoption of Ammonia for Different Shipping/Vessel Segments and Different Geographical Regions}

In terms of geography, Mapping of Zero Emission Pilots and Demonstration Projects, by the Getting to Zero Coalition, mainly identified projects in Europe [19]. However, there has 
been an increase in Asian projects due to an increase and improvement in research methods, as well as an increase in projects originating from Asian countries (the majority from Japan and China, and some from South Korea) [19]. There has been a recent expansion of recent projects in South America related to shipping decarbonization [19]. The Getting to Zero Coalition published a country heatmap illustrating the uptake of pilot and demonstration projects globally. Note that, as already mentioned in Section 1, ammonia in this pilot and demonstration project has a significant proportion, with 11 out of 21 projects in Asia (Japan, China, Korea, and one in Singapore), eight in Europe (Denmark, Norway, Sweden, and one each in Finland and Greece), and the remaining two in Australia and Chile. It is envisioned that the first commercialization of ammonia-related projects will occur in these countries.

Ammonia has a low gravimetric vs. volumetric energy density to meet energy demands. Therefore, ammonia storage will require larger space (there is a similar issue with batteries) and at the moment could thus be limited to short routes. However, the main issue with ammonia is its currently low availability, which is often dominated by the existing supply chain in the fertiliser industry. In other words, ammonia is available where plants (and infrastructure) are already existing for the fertiliser industry.

\section{Economic Performance of Ammonia Compared to Other Shipping Fuels, and Projected Development by 2030 and 2050}

Despite ammonia's excellent properties as either a hydrogen carrier or a direct fuel, the current cost of green ammonia is higher than that of fossil fuels. This is a major barrier to the "widespread adoption" of ammonia "as an energy vector" [58,59]. Blue ammonia will inherently be more expensive than green ammonia due to the extra processing required [58] and the additional infrastructure needed to capture and store $\mathrm{CO}_{2}$. The competition between ammonia and hydrogen, in economic terms, was more comprehensively examined by Cheliotis et al. [23]. The operating expenditure (OPEX) and capital expenditure (CAPEX) of hydrogen and ammonia were examined and compared against diesel fuel as a benchmark. Cheliotis et al. [23] have shown that the CAPEX for an ammonia-based power system is slightly more expensive than that of hydrogen. On the other hand, Zamfirescu and Dincer [16] reported that "ammonia cost per volume of stored energy is three times less expensive than that of hydrogen." Cheliotis et al. [23] further mention that the CAPEX is predicted to be lower compared to the corresponding hydrogen-based power system due to the increasing maturity of the technologies and reduced complexity of ammoniabased systems. CAPEX for diesel fuels is relatively stable compared to ammonia and hydrogen, while the OPEX cost increases due to IMO's deep decarbonization targets. Cheliotis et al. [23] further conclude that it is envisioned that ammonia-powered systems will be the most favourable in economic terms by 2030 .

IRENA [51] reported that green ammonia production costs are currently much higher than those of conventional marine fossil fuels. However, as the technologies mature it is expected that the production cost and renewable electricity costs will continue to decrease, so ammonia technologies will become competitive by 2050 [51]. Wang and Wright [60] conclude that hydrogen, which is one of the main competitors of ammonia, has "high capital costs and uncertainty in fuel supply," whereas ammonia has "several technical key hurdles and safety issues." Moreover, Wang and Wright [60] mention that the dominant driver for conventional ammonia is the price of feedstock in a particular geographical area, which is related to the availability of ammonia's supply chain, similarly to the production costs of hydrogen and methanol.

\section{Regulations Impacting Ammonia's Use as a Shipping Fuel}

Ammonia has on-ship safety implications due to its toxic nature even at low concentrations [21]. Ammonia is also corrosive with certain materials, a fact that must be considered in any design [21]. There are regulations and protocols in place for ammonia as it is transported as cargo; however, some amendments in existing regulations regarding ammonia as a fuel are required. "Class Rules will likely be the earliest regulatory framework in 
place for using ammonia as a fuel" [21]. For example, "one of the important barriers for new fuels such as ammonia and hydrogen is the storage and bunkering infrastructure. This means regulatory actors (Class and Flag) need to collaborate with original equipment manufacturers (OEMs) to enable the uptake" [61].

The relevant code impacting ammonia as a fuel is the International Code for Safety for Ships Using Gases or Other Low-Flashpoint Fuels (IGF) [23]. In particular, "the IGF Code applies to ships to which Part G of International Convention for the Safety of Life at Sea, 1974, as amended (SOLAS) Chapter II-1 applies" [62]. This code was adopted in 2017 and is suitable for natural gas for ICEs, boilers, and gas turbines. Hence, amendments are required to include ammonia as a fuel in ships in the IGF code [23,63]. At the moment, "the IGF Code does not provide prescriptive requirements to cover low flash point fuels such as $\mathrm{NH}_{3}$. It does provide, the mechanism to approve alternative technical design arrangements for the use of low flash point fuels, pending acceptance by the Flag state" [62].

The IGC code Section 16.9, specific to alternative fuels and technologies, states that, if acceptable to the administration, other cargo gases may be used as fuel, with the same safety level as natural gas. However, toxic gases are not permitted for use under this code, and ammonia is considered a toxic gas. Hence, in the long run, the IGC code will require amendments to permit ammonia as a fuel [62]. Until regulations for using ammonia as a fuel are in place, the relevant statutory legislation adopted by the IMO, Flag Administrators, and associated Recognised Organisations for designs on ammonia-powered vessels will need to be based upon the Alternative Design Assessment [21].

\section{Conclusions}

Ammonia is a carbon-free fuel with promising applications as either a direct or indirect hydrogen carrier. Ammonia can play an important role in the decarbonization of the shipping industry, at least for deep sea routes. However, there are a number of key barriers that need to be addressed before its wider use in the shipping industry. These are:

1. High production costs, predominantly due to the high capital costs associated with ammonia's supply chain.

2. Issues with availability, specifically in terms of the number of geographical locations available for ammonia bunkering.

3. Ramping up of ammonia production, since currently ammonia is used for the fertiliser industry.

4. Development of ammonia-specific rules for its use as a maritime fuel. These rules will need to address issues of toxicity, safety, and storage.

The production of green ammonia was investigated and compared to blue ammonia. Green ammonia poses several challenges that need to be addressed, with the most important being the cost compared to production, which currently is significantly higher compared to that of brown ammonia (the production of ammonia with fossil fuels). However, the costs by 2050 are expected to decrease to the same order of magnitude as brown ammonia. The technologies required for carbon capture and storage in the production of blue ammonia are, at the moment, immature. The current literature on shipping-related topics is rather poor regarding issues with blue ammonia. However, conclusions can be drawn from other industries regarding the current general challenges and these are equally applicable to the shipping industry. This is because it is not expected that CCS technologies will be installed onboard ships; rather, such technologies will be used to generate blue ammonia that can be incorporated in the overall supply chain. The general challenges with blue ammonia are:

1. The large energy penalty associated with the overall reduction in the efficiencies of power plants (and associated operational costs);

2. A lack of technical expertise due to the unavailability of plants with CCS;

3. An incorrect public perception regarding the maturity of renewable energy sources compared to the available CCS technologies.

Even though ammonia can be used for transportation and power generation and is an inherently clean fuel compared to traditional pollutants and $\mathrm{CO}_{2}$, it has a century-long 
history of large-scale handling, storage, and use. It is still competitive in terms of energy pricing compared to current fuels. Regardless of the origin of ammonia production (green or blue), for ammonia to be truly zero-carbon its whole lifecycle needs to be considered-a key challenge in the debate on whether ammonia holds promise as a zero-carbon maritime fuel.

Understanding ammonia's combustion characteristics is key to producing cleaner flames. The fundamental characteristics of ammonia-based flames have been studied extensively, but the application of this fuel is still unsatisfactory. Consequently, more research is needed to overcome problems such as the low burning velocity and high emissions of $\mathrm{NO}_{\mathrm{x}}$. In order to fully understand the combustion characteristics of ammonia, developing accurate reaction mechanisms is necessary. This is a major challenge when investigating the combustion of ammonia in simulations. Accurate simulations will help with the appropriate characterization of the digital twinning of internal combustion engines.

Author Contributions: Conceptualization, G.M. and E.A.Y.; methodology, G.M.; formal analysis, G.M. and E.A.Y.; investigation, G.M. and C.I.; resources, G.M.; data curation, G.M.; writing—original draft preparation, G.M. and C.I.; writing—review and editing, G.M., C.I. and E.A.Y.; visualization, G.M. and C.I.; supervision, E.A.Y.; project administration, G.M.; funding acquisition, E.A.Y. All authors have read and agreed to the published version of the manuscript.

Funding: This research was funded by the Cyprus Marine and Maritime Institute (CMMI). The CMMI was established by the CMMI/MaRITeC-X project as a "Centre of Excellence in Marine and Maritime Research, Innovation and Technology Development" and has received funding from the European Union's Horizon 2020 research and innovation program under grant no. 857586 and matching funding from the Government of the Republic of Cyprus.

Institutional Review Board Statement: Not applicable.

Informed Consent Statement: Not applicable.

Data Availability Statement: Not applicable.

Conflicts of Interest: The authors declare no conflict of interest. The funders had no role in the design of the study; in the collection, analyses, or interpretation of data; in the writing of the manuscript, or in the decision to publish the results.

\section{References}

1. Energy Transitions Commission. The First Wave. A Blueprint for Commercial-Scale Zero-Emission Shipping Pilots. A Special Report by the Energy Transitions Commission for the Getting to Zero Coalition; Energy Transitions Commission: London, UK, 2020.

2. Balcombe, P.; Brierley, J.; Lewis, C.; Skatvedt, L.; Speirs, J.; Hawkesa, A.; Staffell, I. How to decarbonise international shipping: Options for fuels, technologies and policies. Energy Convers. Manag. 2019, 182, 72-88. [CrossRef]

3. United Nations Conference on Trade and Development. Gross Domestic Product: Total Per Capita, Growth Rates, Annual. 2019. Available online: https:/ / unctadstat.unctad.org/wds/TableViewer/tableView.aspx?ReportId=109 (accessed on 7 December 2021).

4. DNV-GL. Energy Transition Outlook, Maritime Forecast 2050; DNV-GL: Bærum, Norway, 2019.

5. UN Body Adopts Climate Change Strategy for Shipping. Available online: https://www.imo.org/en/MediaCentre/ PressBriefings/Pages/06GHGinitialstrategy.aspx (accessed on 7 December 2021).

6. Mallouppas, G.; Yfantis, A.E. Decarbonisation in Shipping Industry: A review of research, technology development, and innovation proposals. J. Mar. Sci. Eng. 2021, 9, 415. [CrossRef]

7. McKinlay, C.J.; Turnock, S.R.; Hudson, D.A. Route to zero emission shipping: Hydrogen, ammonia or methanol? Int. J. Hydrogen Energy 2021, 46, 28282-28297. [CrossRef]

8. Milton, R.D.; Cai, R.; Abdellaoui, S.; Leech, D.; De Lacey, A.L.; Pita, M.; Minteer, S.D. Bioelectrochemical Haber-Bosch Process: An Ammonia-Producing H2/N2 Fuel Cell. Angew. Chem. Int. Ed. 2017, 56, 2680-2683. [CrossRef] [PubMed]

9. Kyriakou, V.; Garagounis, I.; Vourros, A.; Vasileiou, E.; Stoukides, M. An Electrochemical Haber-Bosch Process. Joule 2020, 4, 142-158. [CrossRef]

10. Aziz, M.; Wijayanta, A.T.; Nandiyanto, A.B.D. Ammonia as Effective Hydrogen Storage: A Review on Production, Storage and Utilization. Energies 2020, 13, 3062. [CrossRef]

11. IEA. Ammonia Technology Roadmap. Towards More Sustainable Nitrogen Fertiliser Production; International Energy Agency: Paris, France, 2021.

12. Kane, S.P.; Northrop, W.F. Thermochemical Recuperation to Enable Efficient Ammonia-Diesel Dual-Fuel Combustion in a Compression Ignition Engine. Energies 2021, 14, 22. [CrossRef] 
13. International Fertilizer Industry Association. Fertilizers, Climate Change and Enhancing Agricultural Productivity Sustainably; International Fertilizer Industry Association: Paris, France, 2009.

14. Chisalita, D.; Petrescu, L.; Cormos, A.; Cormos, C. Assessing Energy and $\mathrm{CO}_{2}$ Emission Reduction from Ammonia Production by Chemical Looping as Innovative Carbon Capture Technology. In Proceedings of the 28th European Symposium on Computer Aided Process Engineering, Graz, Austria, 10-13 June 2018; Elsevier, B.V.: Graz, Austria, 2018; Volume 43, pp. 1269-1274.

15. Department for Transport. Clean Maritime Plan; Department for Transport: London, UK, 2019.

16. Zamfirescu, C.; Dincer, I. Using ammonia as a sustainable fuel. J. Power Sources 2008, 185, 459-465. [CrossRef]

17. Cames, M.; Wissner, N.; Sutter, J. Ammonia as a Marine Fuel: Risks and Perspectives; Oko-Institut e.V.: Berlin, Germany, 2021.

18. ITF. Decarbonising Maritime Transport. Pathways to Zero-Carbon Shipping by 2035; International Transport Forum: Paris, France, 2018.

19. Fahnestock, J.; Bingham, C. Mapping of Zero Emission Pilots and Demonstration Projects, 2nd ed.; Global Maritime Forum: Copenhagen, Denmark, 2021.

20. Singh, V.; Dincer, I.; Rosen, M. Chapter 4.2-Life Cycle Assessment of Ammonia Production Methods. In Exergetic, Energetic and Environmental Dimensions; Dincer, I., Colpan, C.O., Kizilkan, O., Eds.; Academic Press: Cambridge, MA, USA, 2018 ; pp. 935-955.

21. Fahnestock, J.; Søgaard, K.; Lawson, E.; Kilemo, H.; Stott, C.F.; Stott, S.F. NoGAPS: Nordic Green Ammonia Power Ship; Fürstenberg Maritime Advisory and the Global Maritime Forum: Copenhagen, Denmark, 2021.

22. AGuati-Rojo, A.; Demski, C.; Poortinga, W.; Valera-Medina, A. Public Attitudes and Concerns about Ammonia as an Energy Vector. Energies 2021, 14, 21.

23. Cheliotis, M.; Boulougouris, E.; Trivyza, N.; Theotokatos, G.; Livanos, G.; Mantalos, G.; Stubos, A.; Stamatakis, E.; Venetsanos, A. Review on the Safe Use of Ammonia Fuel Cells in the Maritime Industry. Energies 2021, 14, 3023. [CrossRef]

24. Bourne, C.; Nietsch, T.; Griffiths, D.; Morley, J. Application of Fuel Cells in Surface Ships; Rolls-Royce Strategic Systems Engineering: Derby, UK, 2001.

25. Gray, N.; McDonagh, S.; O'Shea, R.; Smyth, B.; Murphy, J.D. Decarbonising ships, planes and trucks: An analysis of suitable low-carbon fuels for the maritime, aviation and haulage sectors. Adv. Appl. Energy 2021, 1, 100008. [CrossRef]

26. DNV. Use of Methanol Fuel: Methanol as Marin Fuel: Environmental Benefits, Technology Readiness, and Economic Feasibility; DNV: Berum, Norway, 2016.

27. Labrut, M. Maersk Secures Green e-Methanol for World's First Carbon Neutral Container Ship. Seatrade Maritime News. 19 August 2021. Available online: https:/ / www.seatrade-maritime.com/containers/maersk-secures-green-e-methanol-worldsfirst-carbon-neutral-container-ship (accessed on 25 October 2021).

28. MAN Energy Solutions. World-First Order for Methanol Engine within Container Segment. MAN Energy Solutions. 27 July 2021. Available online: https:/ / www.man-es.com/company/press-releases/press-details/2021/07/27/world-first-order-formethanol-engine-within-container-segment (accessed on 25 October 2021).

29. Imhoff, T.B.; Gkantonas, S.; Mastorakos, E. Analysing the Performance of Ammonia Powertrains in the Marine Environment. Energies 2021, 14, 21. [CrossRef]

30. Mørch, C.; Bjerre, A.; Gøttrup, M.; Sorenson, S.; Schramm, J. Ammonia/hydrogen mixtures in an SI-engine: Engine performance and analysis of a proposed fuel system. Fuel 2011, 90, 854-864. [CrossRef]

31. Reiter, A.; Kong, S.-C. Demonstration of compression-ignition engine combustion using ammonia in reducing greenhouse gas emissions. Energy Fuels 2008, 22, 2963-2971. [CrossRef]

32. Wärtsilä. World's First Full Scale Ammonia Engine Test-An Important Step Towards Carbon Free Shipping. Wärtsilä. 30 June 2020. Available online: https:/ / www.wartsila.com/media/news/30-06-2020-world-s-first-full-scale-ammonia-engine-test--an-important-step-towards-carbon-free-shipping-2737809 (accessed on 11 December 2021).

33. Wärtsilä. Wärtsilä Advances Future Fuel Capabilities with First Ammonia Tests. Wärtsilä. 25 March 2020. Available online: https: / / www.wartsila.com/media / news / 25-03-2020-wartsila-advances-future-fuel-capabilities-with-first-ammonia-tests2670619?utm_source=pres (accessed on 11 December 2021).

34. Hansson, J.; Brynolf, S.; Fridell, E.; Lehtveer, M. The potential role of ammonia as marine fuel—Based on energy systems modeling and multi-criteria decision analysis. Sustainability 2020, 12, 3265. [CrossRef]

35. MAN Energy Solutions. Engineering the Future Two-Stroke Green-Ammonia Engine; MAN Energy Solutions: Copenhagen, Denmark, 2019.

36. Win, G.D. WinGD Sets Development Timeframe for Methanol and Ammonia Engines; Winterthur Gas \& Diesel: Busan, Korea, 2021.

37. IRENA. A Pathway to Decarbonise the Shipping Sector by 2050; International Renewable Energy Agency: Abu Dhabi, United Arab Emirates, 2021.

38. Ash, N.; Scarbrough, T. Sailing on Solar: Could Green Ammonia Decarbonise International Shipping? Environmental Defense Fund: London, UK, 2019.

39. Kobayashi, H.; Hayakawa, A.; Somarathne, K.; Kunkuma, A.; Okafor, E.C. Science and technology of ammonia combustion. Proc. Combust. Inst. 2019, 37, 109-133. [CrossRef]

40. Lindstrand, N. Unlocking Ammonia's Potential for Shipping. MAN Energy Solutions. 2021. Available online: https://www.manes.com/discover/two-stroke-ammonia-engine (accessed on 20 October 2021).

41. U.S. Department of Energy. Fuel Cells Fact Sheet; U.S. Department of Energy, Fuel Cell Technologies Office: Washington, DC, USA, 2015 
42. Anjana, N.; Amarnath, A.; Nair, M.H. Toxic hazards of ammonia release and population vulnerability assessment using geographical information system. J. Environ. Manag. 2018, 210, 201-209. [CrossRef] [PubMed]

43. FuelCellWorks. Ammonia Fuel Cells for Deep-Sea Shipping-A Key Piece in the Zero-Emission Puzzle. FuelCellWorks. 29 December 2020. Available online: https:/ / fuelcellsworks.com/news/ammonia-fuel-cells-for-deep-sea-shipping-a-key-piece-inthe-zero-emission-puzzle/ (accessed on 13 December 2021).

44. Barrett, S. ShipFC project on first maritime fuel cell to run on green ammonia. Fuel Cells Bull. 2020, 2020, 5-6.

45. de Vries, N. Safe and Effective Application of Ammonia as a Marine Fuel; Delft University of Technology: Delft, The Netherlands, 2019.

46. Afif, A.; Radenahmad, N.; Cheok, Q.; Shams, S.; Kim, J.H.; Azad, A.K. Ammonia-fed fuel cells: A comprehensive review. Renew. Sustain. Energy Rev. 2016, 60, 822-835. [CrossRef]

47. Kim, K.; Roh, G.; Kim, W.; Chun, K. A Preliminary Study on an Alternative Ship Propulsion System Fueled by Ammonia: Environmental and Economic Assessments. J. Mar. Sci. Eng. 2020, 8, 183. [CrossRef]

48. Al-Hamed, K.H.; Dincer, I. A comparative review of potential ammonia-based carbon capture systems. J. Environ. Manag. 2021, 287, 112357. [CrossRef] [PubMed]

49. Bicer, Y.; Dincer, I. Environmental impact categories of hydrogen and ammonia driven transoceanic maritime vehicles: A comparative evaluation. Int. J. Hydrogen Energy 2018, 43, 23586. [CrossRef]

50. The Royal Society. Ammonia: Zero-Carbon Fertiliser, Fuel and Energy Store; The Royal Society: London, UK, 2020.

51. IRENA. Navigating the Way to a Renewable Future: Solutions to Decarbonise Shipping (Preliminary Findings); International Renewable Energy Agency: Abu Dhabi, United Arab Emirates, 2019.

52. Lewis, J. Fuels without Carbon: Prospects and the Pathway Forward for Zero-Carbon Hydrogen and Ammonia Fuels; Clean Air Task Force: Boston, MA, USA, 2018.

53. Gallucci, M. Why the Shipping Industry is Betting Big on Ammonia. IEEE Spectrum. 23 February 2021. Available online: https: / / spectrum.ieee.org/why-the-shipping-industry-is-betting-big-on-ammonia (accessed on 4 October 2021).

54. Brown, T. Maritime Fuel Mix Could be 25\% Ammonia by 2050. Ammonia Energy Association. 20 September 2019. Available online: https:/ / www.ammoniaenergy.org/articles/maritime-fuel-mix-could-be-25-ammonia-by-2050/ (accessed on 4 October 2021).

55. Haskell, C.; Decarbonising Shipping —Could Ammonia be the Fuel of the Future? Lloyd's Register. 6 May 2021. Available online: https:/ / www.lr.org/en/insights/articles/decarbonising-shipping-ammonia/ (accessed on 5 October 2021).

56. Adamopoulos, A. Regulation is Key to Shipping's Green Push, Lloyd's List Survey Finds. Lloyd's Register. 8 January 2021. Available online: https:/ /lloydslist.maritimeintelligence.informa.com/LL1135333/Regulation-is-key-to-shippings-green-pushLloyds-List-survey-finds (accessed on 5 October 2021).

57. Laval, A.; Hafnia, H.T.; Vestas, S.G. Ammonfuel-An Industrial View of Ammonia as a Marine Fuel. 2020. Available online: https: //hafniabw.com/wp-content/uploads/2020/08/Ammonfuel-Report-an-industrial-view-of-ammonia-as-a-marine-fuel.pdf (accessed on 13 December 2021).

58. Salmon, N.; Banares-Alcantara, R. Green ammonia as a spatial energy vector: A review. Sustain. Energy Fuels 2021, 5, 2814-2839. [CrossRef]

59. Valera-Medina, A.; Xiao, H.; Owen-Jones, M.; David, W.; Bowen, P. Ammonia for power. Prog. Energy Combust. Sci. 2018, 69, 63-102. [CrossRef]

60. Wang, Y.; Wright, L.A. A Comparative Review of Alternative Fuels for the Maritime Sector: Economic, Technology, and Policy Challenges for Clean Energy Implementation. World 2021, 2, 456-481. [CrossRef]

61. Lloyd's Register \& UMAS. Techno-Economic Assessment of Zero-Carbon Fuels; Lloyd's Register \& UMAS: London, UK, 2020.

62. ABS. Sustainability Whitepaper. Ammonia as a Marine Fuel; American Bureau of Shipping: Houston, TX, USA, 2020.

63. Green Shipping Programme. Ammonia as a Marine Fuel Safety Handbook. Green Shipping Programme. 2020. Available online: https:/ / grontskipsfartsprogram.no/wp-content/uploads/2021/01/Ammonia-as-a-Marine-Fuel-Safety-Handbook.pdf (accessed on 4 October 2021). 